\title{
Appraising the Legal Position of Parents Under the Qișās Law: Immunity or A Waiver
}

\author{
Mohd Afandi Awang Hamat(1)
}

\begin{abstract}
Isläm always enjoins the believer to be their brother's keeper. They should protect, respect, and preserve the honor and integrity of their fellow human beings. The religion does not allow any harm to be inflicted upon any person without following the due process of the law. Isläm considers the concept of rendering "justice for all" as a very significant element in its criminal justice system. Thus, the Islāmic law of crimes and torts (jināyāt) spares no expense and defines all the crimes and as well as their prescribed punishments. The law punishes offenders equally regardless of their biological status, sex, affiliation, or background. However, in some circumstances, the law mitigates punishments in favor of specific people without exonerating them in toto from liability. Mitigation of punishment in Isläm therefore, cannot be seen as a grant of immunity since the main objective of the law is to maintain justice amongst all. In recent times, many people hide under the guise of the law in order to take advantage of their actions. Many cases of murder and grievous bodily injuries were alleged to have committed by persons whose responsibilities were to provide protection to their murdered or injured victims. Parents are known to be producers and protectors of their progeny, but quite number of them nowadays are alleged to have committed or aided or abetted the crimes of murder or infliction of bodily harm against their progeny. Hence, this fact cannot be detached from the misconception that is deeply involved in demarcating between "immunity" and "a waiver" under the law of Qișās. It is based on this fact that the paper examines the position of parents vis-a-vis the law of Qișās with a view to differentiate the concept of "waiver" from that of "immunity".

Keywords: Islāmic Criminal Law, Law of Qiṣās, Immunity of Parents, Waiver

$$
\text { ملخصييم الوضبع القانوني للوالدين في القصياص: بين الحصيانة والإعفاء }
$$

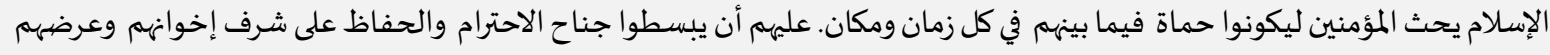

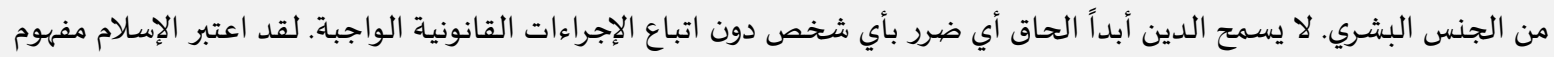

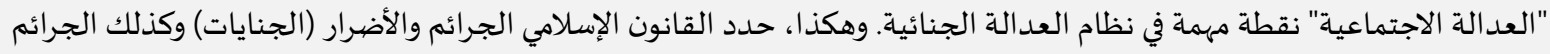

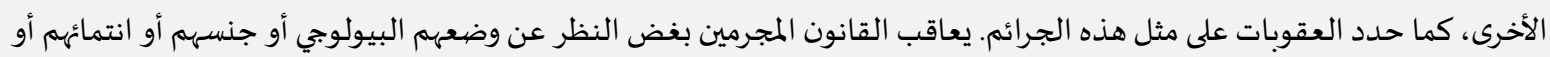

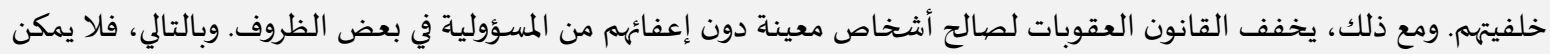

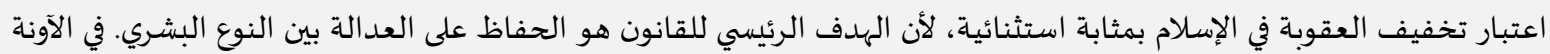

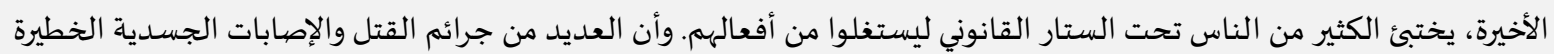

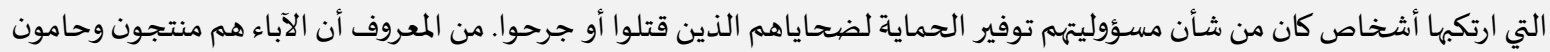

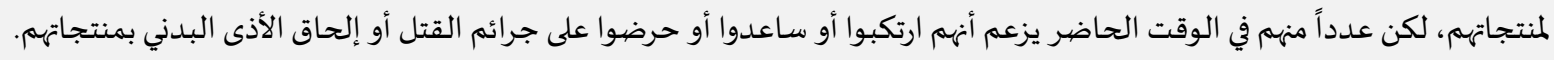

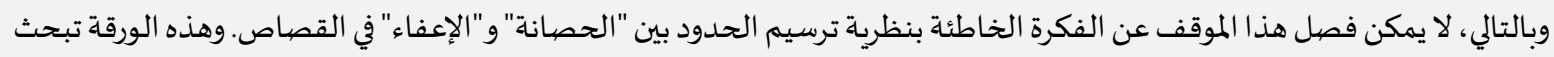
عن حقيقة موقف الشريعة الإسلامية نحو الوالدين فيما يتعلق بالقصاص بين "الحصانة" و"الإعفاء".

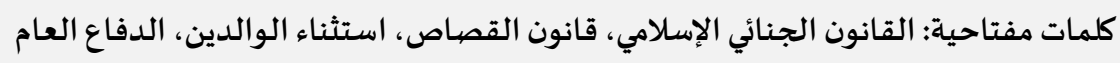

(1) Assist. Prof., Department of Fiqh \& Usul al-Fiqh, International Islamic University Malaysia. mohdaffandi@iium.edu.my

\section{Contents}

Introduction

Qiṣāṣ as a Divine Penalty Under Islāmic Law of Crimes

The Position of Parents under Qișās Rules: Immunity or a Waiver?

The Opinions of the Hanafi, Shāfi $\bar{\imath}$, and Hanbali Legal Schools

The Opinion of the Mālikì Legal School

The Qișās Law: A Need to Explore the Maqāsid al-Sharī'ah (Objectives of Sharī'ah)
Conclusion 51

References

\section{Introduction}

It is a general knowledge to all Muslims that killing a human soul is forbidden in Isläm except in a manner prescribed and provided by Shari 'ah. The prohibition has been prescribed in both the Qur'ān and Sunnah of Prophet Muhammad (S.A.W.). In the Qur'ān, Allāh (S.W.T.) equates killing a human soul (i.e. contrary to 
the stipulations of the law) with the killing of a nation. Thus He says: "Because of that we ordained for the children of Israel that if anyone killed a person not in retaliation of murder, or (and) to spread mischief in the land, it would be as if he killed all mankind, and if anyone saved a live as if he saved the lives of all mankind..." (Qur'ān 5:32) in yet another verse, the Allāh has prepared a grievous punishment for those who commits murder, He says: "And whoever kills a believer intentionally, his recompense is hell, to abide therein, and the Wrath and Curse of Allāh are upon him, and a great punishment is prepared for him" (Qur'ān 4: 93).

In addition, the Prophet (S.A.W) had warned Muslims to desist from doing any act that may cause the loss of a human life, for it is forbidden and indeed a great sin to shed the blood of a human being unjustly. To this end, the Allāh's Apostle says: "The blood of a Muslim who confesses that none has the right to be worshipped but Allāh and that I am His Apostle, cannot be shed except in three cases: In Qiṣāṣ for murder, a married person who commits illegal sexual intercourse and the one who reverts from Islām (apostate) and leaves the Muslims." (Ibnū Baț̣āl, 8:508; al-Bukhārī, 9:83) Similarly, it was narrated by Anas Ibn Mālik that the Prophet (S.A.W) said: "the biggest of al-kabā'ir [the great sins] are to join others as partners in worship with Allāh; to murder a human being; and to be undutiful to one's parents; and to make a false statement or to give a false witness.’(al-Bukhārī, 9:83)

Furthermore, killing a person, apart from its grievous punishment in this life, can have other implications for the murderer in the hereafter, especially regarding their religion and integrity except if they become repented. On the authority of 'Abdullāh Ibn 'Umar (R.A.), the Prophet (S.A.W.) was reported to have said, "A faithful believer remains at liberty regarding his religion unless he kills somebody unlawfully."(Ibnu Battāl, 8:49) This means that if he does not kill, then his integrity, his religion, and his blood are safe and should be protected. This also implies that in Islām, nobody will be allowed to go scot free without being punished for their actions, as the concept of immunity does not exist and does not have room to under Islāmic corpus juris. (Ladan, 2006, 77) On the Day of Judgment the murderer will also be held to account for their actions. To this effect, Abdullāh Ibn Mas ' $\bar{u} d$ reported that the Prophet (S.A.W.) said the first thing that will be decided among people on the Day of Judgement will pertain to bloodshed. (Muslim, 3:1304) This indicates the evil nature and the gravity of the crime in the sight of Allāh. Therefore, whoever is found guilty of murder should be punished in line with the provisions and objectives of Sharī'ah. This is the only way to maintain justice and order in the society. Islām does not only enjoin its followers to do justice but also to ensure that it has been done to all. In Isläm, the concept of rendering "justice for all" has been considered an important element in the creation and existence of the Earth. In fact, it is one of the causes for the creation of the Earth as mentioned in the Qur'ān, in which Allāh (S.W.T.) says:

"Allāh created the heavens and the earth for just ends, and in order that each soul may find the recompense of what it has earned, and none of them be wronged." (Qur'ān 45:22)

Islāmic law cannot be detached from the concept of justice, since all people are equal in the sight of Allāh regardless of their status. (Ladan, 2006, 77) It does not matter whether or not the concerned persons have a special interest or a case to present or protect. Islām places everybody on equal footings regardless of their biological or social status. Thus, it was revealed in the Qur'ān that:

"Allāh Has commanded you to render back your trusts to those to whom they are due; And when ye judge between men, that ye judge with justice." (Qur'ān 4: 58)

This implies the uncompromising nature of doing justice in Islām. It also implies that justice should always be maintained amongst people at all times regardless of their status, position and affiliation. However, in some circumstances, Islāmic law provides for the mitigating factors, the purpose is to enhance the smooth dispensation of justice but not for misuse. It is understood nowadays that people who are privileged by the law, have been misusing it to commit capital offences contrary to the objectives of the Shari' 'ah. In many occasions parents are alleged to have murdered or abetted the murdering of their children or descendants. (Hakīm, 2012, 14) 
Parents have been strongly warned not to kill or participate in the killing their children, as is it is a great sin in the sight of Allāh (S.W.T.). Thus, the Prophet (S.A.W.) was asked as to which sin is greatest in the sight of Allāh (S.W.T.) he replied: "to set a rival unto Allāh though He is the one who created you; to kill your son lest he should share your food with you; to commit illegal sexual intercourse with wife of your neighbour. So Allāh revealed in confirmation of this narration; (Ibnū Battāl, 8:491; al-Bukhārī, 9:83)

"And those who invoke not with Allāh, any other god'. Nor kill such life as Allah has forbidden except for just cause nor commit illegal sexual intercourse. And whoever does this shall receive the punishment.' (Qur'ān 25: 68)

In view of the above background information, this paper attempts to examines jurisprudentially the legal position of parents under Qiṣās law, in an attempt to ascertain their immunity or otherwise. The paper equally explores the role of Maqāsid al-Sharī'ah in Qiṣās law in order to address contemporary challenges.

\section{Qiṣāṣ as a Divine Penalty Under Islāmic Law of Crimes}

The term Qiṣaș is defined as the equal punishment prescribed by Allāh (S.W.T.) against an offender who intentionally causes a victim's death (Qatl-al- 'amd) or inflicts harm on the victim. ${ }^{1}$ Therefore, Qiṣāṣ can be understood generally as a penalty against a crime involving murder or the causing of bodily harm punishable by retaliation or diyah (blood price) in some circumstances.(Anwārullāh, 1997, 76) Even though the victim or his/her relatives have the right to forgive or mitigate the penalty for the accused person. (Ashgar, 2012, 237) To this end, the Almighty Allāh says:

"O you who believe! Al-Qișās (the Law of Equality in Punishment) is prescribed for you in case of murder: the free for free, the slave for slave, and the female for female. But if the killer is forgiven by the brother (or the relatives etc,) of the killed against blood- money, then adhering to it with fairness and payment of the blood-money to the heir should be made in fairness. This is an alleviation and mercy from your Lord. So after this whoever transgress the limits (i.e kills the killer after taking a blood - money), he shall have a painful torment." (Qur'ān 2:178)

Although, the provision has given a victim's relatives or heirs an opportunity to forgive and mitigate the Qiṣāṣ punishment, it is not the intent of the provision and/or any other relevant legislation in the Qur'ān and Sunnah to make transgressors benefit from the privileges provided by the Sharī'ah. Thus, the Mālikī School of Islāmic thought is of the view that the best way to interpret the above verse is to invoke all the rules of interpretation alongside the Maqāsid alSharī'ah. According to this school, some kinds of homicide or bodily injury should not be pardoned by the victim's heirs simply because they have been given powers to do so. For instance, in cases of heinous killings (Qatl al-ghīla), ${ }^{2}$ the Mālikī School of thought emphasized that the waiver should not be entertained due to the nature and surrounding circumstances of the killing. ('Awdah, 1999, 130) Hence the authorities should not allow the perpetrators of such acts to go unpunished.

Protection of lives is the duty incumbent upon the ruling authority, that is why Allāh (S.W.T.) has sent down the revelation through His Messenger (S.A.W.) in order to guide and stabilize the mankind and jinn (super-natural being). Thus, the Allāh Has condemned chaos and bloodshed amongst people, hence He (Allāh S.W.T.) sent down the law of Qișās to be applied and enforced by the constituted authority against any perpetrator of homicide. To this end, He reveals:

"And there is (a saving of) life for you in alQișāṣ (the law of equality in punishment), $O$ men of understanding that you may become Al-Muttāqūn (the pious)." (Qur'ān 2: 179)

In yet another verse:

"And do not kill anyone whose killing Allāh has forbidden, except for a just cause. And whoever is killed wrongfully (Mazlūman intentionally with hostility and oppression and not by mistake), we have given his heirs the authority (to demand Qiṣașs)". (Qur'ān 17:33)

In a situation where Qișās has not been executed, and there was no any legal justification for lack of the execution; or in a situation where the accused person absconded justice, Islām has equally provided the punishments for such cases in the 
hereafter, when everybody should be asked to account for his/her deeds. Thus, Allāh (S.W.T.) says:

"And whoever kills a believer intentionally, his recompense is hell, to abide therein, and the Wrath and Curse of Allāh are upon him, and a great punishment is prepared for him." (Qur'ān 4:93)

Despite the fact that the punishment of Qiṣās (retaliation) originated from the Qur'ān and Hadìth of the Prophet (S.A.W.), there are differences of opinions concerning the term of reference for Qișās. That is to say, whether or not the application of Qișās can only be limited to retaliation of murder (i.e. death penalty) alone; or it can also cover other aspects of retaliation such as infliction of bodily injury. To this end, the opinion of the majority of Muslim jurists is that the Qiṣāṣ deals with both the retaliation of murder and bodily injury. (Anwārullāh, 35) This position is based on some provisions of Qur'ān and Sunnah, as well as the opinions of the Islāmic jurists (fuqaha $\left.\bar{a}^{\prime}\right)$ in line with the Maqāsid al-Sharī'ah (Objective of Islāmic Law). Therefore, in the Qur'ān, Allāh (S.W.T.) reveals:

"And we ordained therein for them: life for life, eye for eye, nose for nose, ear for ear, tooth for tooth, and wound equal for equal. But if anyone remits retaliation by way of charity, it shall be for him expiation. And whosoever does not judge by that which Allāh has revealed, such are the Zälimūn (polytheists and wrongdoers- of a lesser degree)." (Qur'ān 5: 45)

From the foregoing verse, it has been implied that Qiṣaș deals with both homicide and bodily injury hence it is applicable to both. However, some jurists still hold the opinion that it can be subjected to different interpretations, especially when it relates to the issue of retaliation for general injuries not the specific ones as mentioned in the verse. (Ahmed, 2008, 136) For instance, it was narrated that Imām Mālik maintained the position that a father shall be subjected to Qiṣa $\bar{s}$ for killing his child if the motive of the murder does not involve doubt as to the deliberate intent of his action. He (Imām Mālik) however further says that a father should not be liable to Qiṣạs for injury intentionally inflicted by him on his child. (Ahmed, 2008, 136) This latter position of Imām Mālik could not be detached from the effect of the differences of opinions bedevilling the term of reference concerning Qiṣāṣ in Islāmic jurisprudence.
To further buttress the application of Qiṣa $\bar{a}$ on the retaliation for injuries, the Prophet (S.A.W.) in a hadīth narrated by Anas Ibn Mālik, said: “A Jew crushed the head of a girl between two stones. It was said to her. 'Who has done this to you, such-and-such person, such-and-such person?' When the name of the Jew was mentioned, she nodded with her head, agreeing. So the Jew was brought and he confessed. The Prophet (S.A.W.) ordered that his head be crushed with the stones. (Hammam said, 'with two stones.')" (Ibnū Battāl, 8:513; al-Bukhārī, 9:23) In a similar hadīth narrated by Ibn 'Abbās that the Prophet (S.A.W.) said, "This and this are the same." He meant the little finger and the thumb in respect of Qiṣās. (Ibnū Battāl, 8:523; al-Bukhārī, 9:33) These two hadīth have negated the position taken by some scholars who upheld the opinion that Qiṣas ș should be applied only to homicide; and that the law of Qișās for injuries is set out based on Ijmác (consensus opinion of Muslim jurists). (Hakīm, 2012, 14) However, based on the above authorities cited earlier, it is clear evidence that Qiṣass is not restricted only to retaliation for murder but also for the infliction of injury. Islāmic jurists have also affirmed that the law of Qiṣās should also be applied to cases of injury provided that the following conditions are fulfilled, namely: the injury must be intentional ('amd); there must be equality in application; and the execution of Qiṣas must be practicable in such a way that it will not lead to the death of the culprit. (Hakīm, 2012 , 14) This is the view of jurists in Mālikī and Shafi'‘̄ schools of Islāmic thought. However, according to Hanafĩ jurists, the application of Qișạs for injuries can be done if the injury reaches the skull bone (almuwaddaha) and as well, the Qiṣāṣ should be for a particular injury (al-jināya ala-mifsal ). (Hakīm, 2012, 14)

Qiṣāṣ in Islāmic law is aimed at ensuring equality amongst the people, thus some scholars have made efforts to distinguish Qiṣāṣ from a revenge simpliciter. (Qutb, 71) In the latter case (i.e. revenge), the punishment inflicted on the offender is neither equal nor similar, and sometimes innocent people can become a victim of revenge. While in the former case (i.e. Qișās), the equality of quantity of crime and punishment is strictly adhered to. The Qișās law requires that the victim's kin should not inflict a greater 
degree of harm than that which has been inflicted on the victim. Hence it should be equal otherwise the Qiṣāṣ would be prohibited. (Ahmed, 136) The same thing will happen if the equality in awarding punishment by way of Qișạs is not practicable or possible, thus, some other alternative punishments are awarded instead. Furthermore, the process of revenge in most cases are informal while Qiṣāṣ is done in a formal way, which at all times is awarded by the order of the court or constituted authority. It is therefore required for the entire community to assist the authority and the victim in execution of Qiṣāṣ. (Hakīm, 14)

It is important to understand that the rationale behind the revelation of Qiṣās (retaliation) in the Qur'ān and Sunnah of the Prophet (S.A.W.) is to bring sanity and order amongst the Ummah (Muslim community). (Mamman, 2011, 9) Islām does not allow those who can intentionally kill their fellow human beings to take advantage of the law and go scot free, as it is the aim of the religion to protect and preserve human lives. Similarly, based on the provisions in the Qur'ān and Sunnah one may equally draw a conclusion that the aim of Qiṣās is to maintain justice among all, thereby subjecting murderers to reap what they sow in a like manner. This is what the equality entails in Sharī'ah. Thus, Sayyid Qutb said that the principle of human equality for deliberate murder is life for life. (Qutb, 71)

The application of Qiṣās for injuries (Qiṣāṣ mā dūn al-Nafs) has been therefore agreed and upheld by large number of Muslim jurists. It can be imposed by retaliation upon someone who has deliberately inflicted injury or harm on his/her fellow beings. However, according to the views of the Mālikī and Hanafì jurists, such retaliation shall be carried out after the victim's wounds have healed, this is to clear an accused person from any death liability that may arise to replace the liability for bodily harm. To this effect, the Mālikī jurists are of the view that in a situation like this, the operation must be carried out by a physician, which is to be paid for by the plaintiff. Other schools of Islāmic jurisprudence with the exception of the Mālikī school agree on the immediate execution of the convict. (Rudolph, 2005, 36)

Furthermore, the prosecution of death penalty varies according the schools of jurisprudence. Thus, according to the majority of schools, the death penalty can be carried out by an executioner. However, the Mālikī and Shāfi' $\overline{1}$ jurists are of the opinion that the penalty can be executed by one of the victim's heirs with permission and supervision of the authority. (Rudolph, 2005, 36) The basis of their argument is on the last part of the verse in the Holy Qur'ān, which provide that:

"We have given his heirs the authority (to demand Qișāṣ)”. (Qur'ān 17:33)

The verse is categorical by saying that the authority is given to the victim's heirs to demand Qiṣa $\bar{s}$ i.e to seek permission from the authority. Therefore, if they went ahead to prosecute Qișās punishment without the grant of permission from the authority, they can be liable for a discretionary punishment measure $(T a ' z \bar{\imath} r)^{3}$ but not Qiṣās. (Rudolph, 2005, 36) Similarly, the manner upon which the execution is to be conducted is also controversial. According to Hanafi jurists, the execution can be done by the sword, for it is the best and most comfortable way of execution. It is always required in Islām to invoke righteousness while executing a penalty based on the reason that Allāh (S.W.T.) reveals:

"And We gave him good in this world, and in the hereafter he shall be of the Righteous." (Qur'ān 16: 126)

In yet another verse:

"The sacred month is for the sacred month, and for the prohibited things, there is a law of equality (Qișās). Then whoever transgresses the prohibition against you, you transgress likewise against him. And fear Allāh, and know that Allāh is with Al-Muttaqūn" (Qur'ān 2: 194)

In a hadith reported by Muslim, the Prophet (S.A.W.) says:

"Verily, Allāh has enjoined excellence (ihsān) with regard to everything. So, when you kill, kill in a good way; when you slaughter, slaughter in a good way; so every one of you should sharpen his knife, and let the slaughtered animal die comfortably." (Bādī, 2013, 89)

However, majority of jurists in the Sunni madhāhib (the Sunni schools of thought) are of the opinion that death shall be inflicted in the same manner 
as the victim was killed. Except that if the method to be used would result in protracted torture, in this circumstance other methods such as using sword will be adopted. (Rudolph, 2005, 36) The law of Qiṣās is ordained by Allah (S.W.T.) to be applied and enforced amongst people in an excellent manner. The application of the law serves many purposes which among other things include: guaranteeing the peaceful survival of people in the society, maintaining equality amongst people, giving the victim's relatives a sense of belonging. hence by giving them opportunity to seek for retaliation or reception of Diyah (blood money) in some peculiar circumstances. The Qiṣāṣ law according to Imām Amīn Ahsān Islāhī, gives the public a legal protection against the evil action of violators of the law (i.e. murderers); it provides a kind of relief to the victim's relatives. In fact, the Qur'ān provides that the application of Qișās in capital offences is like giving life to the slain person (Qur'ān 2:179); and finally, the Qiṣās law makes everybody in the society to be law abiding and dutiful to one another. ${ }^{4}$

\section{The Position of Parents under Qișāṣ Rules: Immunity or a Waiver}

It is a general principle under the Islāmic law of crimes that if one has killed an innocent soul or inflicted grievous injury on a person, they should be subjected to the same act. This is contained in the Qur'ān, in which the Allāh (S.W.T.) prescribed for the believers in a case of murder the law of equality in punishment; this is in order to alleviate in justice here on the earth and to bestow mercy on mankind on the Day hereafter. (Qur'ān 2:178) Allāh (S.W.T.) further explains in another verse on how the principles of equality should be exercised. Thus, He (Allāh) provides that if one kills he should be killed; or if one removes someone's bod part should he be subjected to the same act; or if one injures his fellow human being he should be inflicted with the same injury. (Qur'ān 5: 45) However, just like any general rule, there must be exception. Hence, parents are exempted from being subjected to Qiṣās under the Islāmic law of crimes. The Prophet (S.A.W.) in a hadith, was reported to have exempted the parents from being subjected to Qișās. Based on this, jurists from various schools of thought have held different views. The majority of jurists are of the views that parents should not be subjected to Qiṣās, while some jurists upheld that parents should not be an exception to the rule as far as the Shari'ah is concerned. Furthermore, all Sunni legal schools, except the Mālikīs, have unanimously agreed on the exemption of parents from Qișās. Below are the opinions of various Islāmic legal schools.

\section{The Opinions of the Ḥanafī, Shāfi‘ī and Hanbalī Legal Schools:}

These schools of thoughts are of the view that a parent should not be subject to death as a result of killing their child. This is based on the popular hadīth of the Prophet (S.A.W.) that a parent should not be subjected to Qișās for killing or harming their child. The Hadìth has been tagged with a specific application due to generic nature of the verse in the $Q u r^{\prime} \bar{a} n$ that mandates the application of Qiṣa ș (retaliatory punishments) against murderers. In other words, the Hadith can be considered as the exception to the general rule that provides for the application of Qiṣāṣ as contained in the Qur'ān. (Qur'ān 2: 178; Qur'ān 5: 45) Similarly, according to these legal schools, the position is also the same as in a case of a master killing his slave; hence the former should not be subjected to Qiṣās. The legal schools have based their arguments on the pProphetic Hadith which explained the Qiṣaș waiver that was upheld by 'Umar Ibn Al-Khattāb (R.A.) in the case of a farther who was reported to have killed his son. (Al-Jazīrī, 2003, 132) To this end, Imām al-Sarakhsī (the Hanafī jurist), is of the view that homicide is forbidden by Allāh (S.W.T.) and it is a "Qiṣāṣ" punishable offence. However, he maintained that parents should not be subjected to Qișāṣ. (al-Sarakhsīi, 2000, 78) Similarly, Al-Samarqandī (a Hanafì jurist) also confirmed the above position but he added that, in a situation like this, such parents should be made to pay the diyah (blood price) to the rest of the deceased heir. (al-Samarqandī, 1984, 3:119) Another Hanafī jurist, Abū Bakr Ibn Mas'ūd elaborated further, that the waiver should not be restricted to the fathers alone, but also to the grandparents and maternal parents. ('Ala' al-Dīn, 1986, 335)

According to the Shāfi'ite jurist, Yahya Ibn Sharaf, parents (whether paternal or maternal, whether 
direct or ascendants parents) should not be subjected to Qiṣās. (al-Nawawī, 1991) This juristic opinion is based on the opinion of the founder of the school (Muhammad Idrīs al-Shāfi ‘̄̄) himself in his book called "Al- 'Umm”. Thus, he said, no Qiṣạs should be executed against parents or the ascendants.(al-Shāfi' $\overline{1}, 1973,6: 34)$ AlMāwardī also relying on the opinion of his school of thought (the Shāfi'i $\overline{1}$ school) added that whether the parent crucifies or slaughters his child as opined by the Mālikī School of thought, should not be subjected to Qiṣāṣ.(al-Māwardī, 1994, 12:22) However, alMurdawī (a Hanbalī jurist) has emphasized that a parent can only be exempted from being subjected to Qișâs provided that the victim is his legitimate child and not a walad al-zinā (an illegitimate child or a child begotten outside of wedlock). (al- Murdawī, 1998, 9:350) He should be asked to pay diyah, and will be barred from inheritance. (al- Murdawī, 1998, 9:350) In addition, Ibn Qudāmah is of the view that the Qiṣās waiver should not be restricted to direct parents alone, but that grandparents also be included. (Ibn Qudāmah, 10:1968)

\section{The Opinion of the Mālikī Legal School:}

This legal school has upheld a different opinion from the previous three. According to the Mālikī legal school, a parent should not be subjected to Qiṣās merely by killing or inflicting grievous injury on their child, provided that the act committed by him was done unintentionally or was not heinously done. The legal school also maintained that the parent should be asked to pay diyah (blood money) instead, and to be barred from inheriting from the diyah. (al-Qurtubī, 2:1097) However, if the homicide was committed intentionally by a parent, for instance, if he slaughtered or crucified his child, he will not be protected by the hadith to escape the Qiṣās. (Ibn Rushd, 2004, 184) For it is not the intent of the Shari'ah to grant immunity to transgressors. More so, the provision of the Qur'ān (on Qișâs) is categorical and generic in nature. (Qur'ān 2: 178; Qur'ān 4: 45) It applies to every Muslim regardless of his/her status; hence it is a trite under the principles of Shari'ah, that everyone should be responsible for his/her action or omission. Thus, jurists in the Mālikī legal school maintain that subjecting parents to Qiṣa $\bar{s}$ depends always on whether they have intended the results of their action. (al-Jazīrī, 2003, 132) If the act or omission leading to a death or injury of the child was carried out intentionally, then the parent will be subject to Qiṣaș. But if it was unintentional, then he will only be subject to diyah and should also be prevented from inheriting from the diyah. ('Abd al-Wahhāb, 2004, 2:183) ${ }^{5}$ To this end, some muftīs in their various fatāwa have upheld the opinion of Mālikī legal school with a willingness to explore the dynamism of Islāmic law in contemporary society.

One of the fatāwa $\bar{a}$ issued was that a parent who kills his child intentionally or heinously should equally be sentenced to death. ('Abd al-Wahhāb, 2004, 2:183) In addition, some scholars have emphasized that diyah should equally be imposed on such a parent alongside Qișāṣ. (al-Baghdādī, 1:184) Even though, this latter opinion has been subjected to series of criticisms by quite number of jurists; the basis of this fatwa is the provisions of the Qur'ān and the Sunnah of the Prophet (S.A.W.). In the Qur'ān, Allāh (S.W.T.) has generally made it forbidden on parents to kill their children. Thus, He says: "And when the female (infant) buried alive (as the pagan Arabs used to do) is questioned: For what sin was she killed?" (Qur'ān 81: 8-9) This verse implies that killing of children by their parents for whatever reason is not allowed in Islām, as it was the practice of pagan during the Jāhiliyyah period (the pre-Islāmic period). This has also been confirmed by the hadith of the Prophet (S.A.W.), which was narrated by Mughīrah Ibn Shu 'bah, that the Prophet (S.A.W.) says: "Allah has forbidden for you: to be undutiful to your parents; to bury your daughters alive (i.e. to kill them); not to pay the right of others (Zakāt); and to beg of men (begging)..." (al-Bukhārī, 3:591) By this hadìth, it can be understood that killing is a capital offence in Islām, for which the perpetrators should not be allowed to go unpunished.. Similarly, Islām does not allow killing of children even in the name of discipline. This can be inferred from the provision in the Qur'ān, which says:

"Say O Muhammad, come I will recite for you what your Lord Has prohibited you from: Join not anything in worship with Him; be good and dutiful to your parents; kill not your children because of poverty- We provide sustenance for you and for them; come not near to Al-Fawāhish (shameful sins) whether committed 
openly or secretly; and kill not anyone whom Allah has forbidden except for a just cause. This he has commanded you that you may understand." (Qur'ān 6. 151)

In another verse of the Qur'ān, Allāh has prepared for murderers a grave punishment in the hereafter. Thus He says:

"And whoever kills a believer intentionally, his recompense is Hell to abide therein; and the wrath and curse of Allāh are upon him, and a great punishment is prepared for him." (Qur'ān 4: 93)

In a hadìth narrated by Ibn 'Umar (R.A.), the Prophet (S.A.W.) said: "a faithful believer remains at liberty regarding his religion, unless he kills somebody unlawfully.” (Ibn Hajar, 1959, 12:188) This combination of the above authorities quoted from the Qur'ān and Sunnah imply the gravity of intentional homicide in Isläm, to the extent that one may lose his faith and consequently abide in the hell in the hereafter. Meanwhile, the above authorities did not in any way exempt anybody from the criminal liability since both authorities have used the phrase "a believer" to mean everyone regardless of status and background. Therefore, had Allāh (S.W.T.) wanted to exonerate parents who intentionally kill their children from the punishment of Qișās, He would not have revealed such generic provisions which imply that murderers are not believers.

However, according to other views, a parent should not be subjected to Qiṣaṣ for killing their child or inflicting injury on him/her. This is based on the hadith of the Prophet (S.A.W.) which was narrated by Ahmad and Tirmidhī that he/she should not be killed. Of course, the hadīth has been declared as authentic and sound by Al-Baihaq̄i and AlBān̄̄. But alternatively, Albānī maintained that such parents should be asked to pay diyah, in which he should not be allowed to benefit (inherit) from it. To this end, it was reported that a man from the clan of Ban̄̄ Mudlij (who was called Abū Qatādah) killed his child and was asked to pay diyah (100 camels) by 'Umar Ibn Al-Khattāb (R.A.) AlBānī declared the hadīth as sound. (Al-Albāni, 1985, 7: $269)^{6}$ This has been the opinions of 'Umar Ibn AlKhattāb and 'Alī Ibn Abī Tālib (R.A.), based on the pProphetic tradition that forbids inheritance between a murderer and his victim (deceased). (Al-Albāni, 1985, 7: 269)

Furthermore, it has been opined that one of the reasons attached to the interpretations of the hadith that exempted parents from being subjected to Qiṣās is because of their status as biological producers of the children. The presumption is that a parent who gave birth to a child should not deliberately kill the child. Therefore, according to such scholars, parents should be given a benefit of doubt and privilege by virtue of their status. More so, Allāh (S.W.T.), as a mark of honour to parents, has linked the obligation on people to worship Him alone with the requirement of being dutiful and obedient to parents within a single statement. Thus He says:

"And your Lord has decreed that you worship none but him. And that you be dutiful to your parents. If one of them or both of them attain old age in your life, say not to them a word of disrespect, nor shout at them but address them in terms of honour." (Qur'ān 17: 23)

In yet another verse:

"We have enjoined on man to be good and dutiful to his parents; but if they strive to make you join with Me (in worship) anything (as a partner) of which you have no knowledge, then obey them not. Unto Me is your return and I shall tell you what you used to do." (Qur'ān 29: 8)

The above verses have shown the extent of the relationship between parents and children, as well as the duty of children towards their parents. Such relationship implies that under normal circumstances, a parent should not terminate the life of his child. In view of this and going by the relevant authorities from the Qur'ān and Sunnah, all the Sunnī legal schools except the Mālikī school, maintained that parents should not be subjected to Qiṣāṣ in all circumstances. Imām Mālik, Ibn Nāfi 'i, Ibn a-hākim, Ibn Al-Mandhar among others affirm the necessity of subjecting parents (who intentionally kill their children) to Qiṣāṣ. In fact, scholars have divergent opinions regarding the authenticity of the hadith which was reported that 'Umar Ibn Al-Khattāb (R.A.) refused to execute a father who killed his own child, based on the reason that the Prophet (S.A.W.) disapproved same. Some Islāmic jurists have denied the authenticity of that Hadith, 
among such jurists include: 'Alī Ibn Al-Madīn̄i, AlTirmidhī, Ibn Al-Qittān, 'Abd Al- Haqq Al- Ashbailī, Aḥmad Shākir and Shu'aib Al- Arna'ūt who also confirm the lack of the authenticity of the hadìth in his book called: "Tahqīq Al -Musnad". 7 In contrast, Shaikh Albānī in his Irwā'i Al-Ghalīl confirmed the authenticity of the hadīth, while maintains that a parent should not be subjected to Qiṣāṣ. (Al-Albāni, 1985, 7: 269) Albānī, has also cited a related ahādith to buttress the position of the hadīth that waived Qiṣ̄ṣ against parents. He cited that a hadìth reported by Abī Da'ūd, from the authority of 'Amr Ibn Shu'aib, from his father, from his grandfather; verily! A man came to the Prophet (S.A.W.) lamenting that he has a wealth, but his father demanded to take over it. The Prophet (S.A.W.) replied him that "Both you and your wealth belong to your father, that, your children are the best means of your livelihood, hence you can eat and use from their wealth." The hadith has been authenticated and declared sound by Albānī. (Al-Albāni, 1985, 7: 269)

In conclusion, the most accepted opinion (Qawl al-Räjih) here is that parents who kill their children intentionally, should be subjected to Qiṣās. They should not be covered by such hadīth. ${ }^{8}$ This is based on the following reasons: that the verses of the $Q u r^{\prime} \bar{a} n$ are generic about the prohibition and punishment of homicide; that there is doubt as to the authenticity or intent of the hadith itself; that there should be a need to upheld Maqāsid al-Sharī' 'ah; and that there should be a need to upheld the principle of shadd al dharīah (blocking the evils). According to Muhammad AlAmīn al-Shanqītī in Adwa' al-Bayān, the verses of the Qur'ān 178-179 is a clear indication that Islām propagates that justice should be done to all and it should be for all regardless of individual status or background. The aim of Qiṣas is to subject a culprit to the same action they inflicted on the victim.

Islām is a unique religion, and out of its uniqueness, it encourages moderation (wasatiyyah) in all affairs. Unlike the Yahūd (Jews) who normally holds the extremist positions, and Nasārā (Christians) who always maintain the lowest and least position, Islām always operates on moderate position. The Prophet Muhammad (S.A.W.) was reported to have said: "The
Religion (Islām) is very easy and whoever overburdens himself in his religion will not be able to continue in that way. So you should not be extremists, but try to be near to perfection and receive the good tidings that you will be rewarded; and gain strength by worshipping in the mornings, the nights."9 In a similar tradition, though it has been declared weak by Albānī, the Prophet (S.A.W.) says: "The best of all affairs is moderate of all." 10

The law governing Qiṣāṣ is derived from the Glorious Qur'ān and Sunnah of the Prophet (S.A.W.). It shall be applied against all persons convicted for homicide and serious bodily injury (grievous hurt). The maqșad (objective) of the Qișās is to punish the offenders and at the same time deter other people from committing same, as nobody is above the law. The law is fair, just and objective, hence it provides equal treatment to all people. However, some people such as parents have been granted waiver from being sentenced to death as a result of killing their products. ('Audah, 130) But the waiver cannot be seen or understood as immunity or total exoneration from Qiṣāṣ. (Anwārullāh, 76) The waiver does not change the general position of the law, rather it mitigates the punishment to a lesser one. The waiver can be benefited from if certain conditions are fulfilled, for instance Qișās can be waived if a parent did not kill their child intentionally. But if they kill the child deliberately or heinously, then they should stand to forfeit that privilege. This is different from the position of being immune, in which they could be exonerated from Qiṣa in all circumstances.

The essence of waiving the Qiṣa against parents is to give them a benefit of doubt regarding their state of mind (guilty mind), since the general presumption is that parents cannot kill their progeny. However, in a situation where it is proved that they have committed the offence intentionally or heinously, then they forfeit the privilege. Thus, parents are advised not to use this as a license for commission of an offence, because the purpose (maqsad) of the law is not to award them immunity but to accord them with privilege for the purpose of being parents. Therefore, if the maqsad has been negated, then the actual position of Sharī'ah will equally change. To this end, a father or 
his ascendants who has intentionally killed his child or descendent should not be subjected to Qișāṣ according the general principle of Sharī'ah. However, if he did that heinously or in such a manner contrary to the principle of humanity, should be liable for Qișās and be punished accordingly. According to the popular opinion of jurists (mashhūr), a father should not be sentenced to death if he kills his biological child; this is based on the tradition of the Prophet (S.A.W.) that says, a father should not be killed as a result of killing his child. Because he is the one that brought the child to see the light of the day, hence he is not expected to deliberately kill the child. ${ }^{11}$ That is the interpretation upheld by the majority of Islāmic jurists.

The issues that can be raised from the hadith that disallowed Qiṣās to be executed on parents inter alia include the following: Does the exoneration of a parent from Qișās cover all kinds of homicide? Can the Qișās waiver be extended to persons other than first parents of the victims such as their ascendants (grandparents)? Does it apply only to the paternal parents or both paternal and maternal? What then should be done to a parent who kills his child? Should they be just killed in the like manner or should they be asked to pay Diyah or should they be punished by way of $t a{ }^{\prime} z \bar{\imath} r$ (discretionary punishment)? Or should they be allowed to go scot free? What should be the adequate interpretation of the prophetic hadīth that waived Qiṣās to be executed against parents, taking into cognizance some provisions of the Qur'ān, Hadìth, Maqāsid alSharī'ah, as well as contemporary challenges?

In respect to the first issue as to whether or not the Qișās waiver should be granted to all kinds of homicides is a question of both law and jurisprudence. Jurists are unanimous on the issue that not all killings should be granted a waiver. (Anwārullāh, 76) There are some cases where a waiver should be granted to the murderer, while in some cases the murderer should be executed by way of Qișās. (Anwārullāh, 76) To this end, according to Jumhūr, based on the tradition of the Prophet (S.A.W.), a father (murderer) should not be killed merely because of killing his child. (Ahmad, $1999,1: 292)$ This is also the position of some of the Prophet's companions such as 'Umar Ibn al-Khattāb (R.A.) and 'Alī Ibn Abī Ṭālib (R.A.). However, some of the followers of the Prophet's companions maintained that a father should be killed if he intentionally murdered or slaughtered or stabbed or crucified his child to death. This is also the opinion of Imām Mālik as well as jurists under his school of thought. Similarly, Imām al- Qurtubī is of the opinion that the punishment of Qiṣās should be subjected to the intent of the father. If he intends his action, then he should also be killed, whereas if he intends not, then he should be ordered to pay diyah and observe Kaffārah. (al-Jazirī, 2003, 132) Alternatively according to an opinion, he can only be punished by way of ta 'azīr (discretionary punishment) since no specific punishment has been prescribed for it. (al-Jazirī, 2003, 132)

In contrast, Imām Shāfí'‘̄, Abu Hanīfah and Imām Hanbal were of the view that a father should not be killed as a result of killing his child. (Al-Qazwīni, $2: 888)^{12}$ Therefore, based on the juristic views and opinions of jumhūr, one may conclude that under the general rule of Qiṣās, and Maqāsid al-Sharī'ah, a father should not be subjected to Qiṣās. However, when he intentionally, or treacherously, or heinously caused the death of his child, he should equally be sentenced to death.

Regarding the issue as to whether or not the privilege or Qișās waiver should be extended to ascendants or to the maternal parents is also the questions of both law and jurisprudence. Islāmic jurists upheld different views in this regard. Some are of the views that the Prophetic tradition is categorical and explicit on the matter, i.e it has mentioned only wālid (a father) and walad (a child) no more. On the other hand, some jurists are of the views that based on the rules of interpretation of Sharī'ah, that the term wālid is all encompassing; it comprises wālidah (a female parent) as well as grandparents (ascendants). (Anwārullāh, 76) That is to say, "what is good for the goose is also good for the gander". The rule will cover both the maternal and ascendants parents. The same thing applies to the term walad (a child); it comprises also the grandchild (a descendent). Therefore, if a grandparent (how-high-so-ever) kills his grandchild (how-low-so-ever) should not be sentenced to death subject to the rules and conditions of Qișāṣ. Similarly, Ibn 'Uthaimin is of the view that, the waiver does not cover only a father but also mother. He equally 
maintained that the grandparents are also inclusive in the waiver. ${ }^{13}$ However, unlike in the case of parents, scholars are of the opinion that the waiver does not exonerate children from Qiṣạs whenever they are guilty of murdering their parents, ('Audah, 130) neither does it also exonerate maternal grandparents since the concept of linage in Islām is determined paternally. ${ }^{14}$ Be that as it may, one thing is certain, that in whatever circumstances or whichever capacity parents happened to be, the punishment should not be waived completely in their favour; they can be punished by way of $t a$ ' $z \bar{\imath} r$ or they can be asked to pay diyah or both. On the issue of diyah, Albānī15 narrated that 'Umar (R.A.) had said, the father should not be killed for his child murder, instead, he should be mandated to pay the diyah (blood money). (Al-Tirmidhī, 4:18)

\section{The Qișāṣ Law: A Need To Explore The} Maqāsid al-Sharī'ah (Objectives of Sharī'ah)

The fundamental objective of Qiṣa ș under Islāmic law of crimes is to protect human lives and maintain justice amongst all. Human lives are sacred and should not be taken except by following due process of the law. To this end, Allāh (S.W.T.) says:

“...And kill not anyone whom Allāh has forbidden except for a just cause (according to Islāmic law)”. (Qur'ān 6:151)

Similarly, it was narrated by Ibn Mas' $\bar{u} d$ that the Prophet (S.A.W.) said:

"The blood of a man who is a Muslim is not lawful (i.e. cannot be lawfully shed), save if he belongs to one of three (classes): a married man who is an adulterer; life for a life (i.e. for murder); one who is a deserter of his religion, abandoning the community." (Badi, 2013, 75)

The foregoing provisions confirm the need for the application of Qiṣa become even more necessary in this contemporary society where systematic violations of human rights by those who ordinarily are supposed to protect such lives are rampant. Many children nowadays are reported to have been killed by their parents on different occasions. In view of this, it is paramount to explore the Maqāsid al-Sharī'ah (objectives of Sharī'ah) in the application of Qiṣa ș in this contemporary society. This can assist in reducing the rate of the crime in the society. In fact it is high time for people to rely on the classical approach in determining issues bothering on Islāmic law in the contemporary society. More so, Islām is a dynamic religion which always develops with time and place. Therefore, this feature of dynamism should be utilized to achieve the objectives of Shari' 'ah. In view of the fact that Qișạs law has been set out to guarantee the security of lives of the entire society, it should always be considered on priority of all situations. Qiṣās cannot be seen as taking another human life as criticized by some antagonists of Islāmic law. This is based on the fact that if the Qiṣās punishment has not been carried out, the mental disorder in which a person commits the crime will actually transmit to the society; and the result is the pollution and lawlessness of the whole society. A society in its collective capacity is just like a body whereby if one of its parts infected, the whole body get affected. 16

Furthermore, since the law of Qișās was primarily revealed in order to maintain justice in the society, it is therefore important for the constituted authorities within Muslims societies to ensure that the aim justifies the means. They could do that by making recourse to a liberal and dynamic way of interpreting the principles of Sharī'ah in line with its Maqāsid. It is not the aim of Islāmic law to exonerate some people from being criminally responsible for some offences, but only to mitigate the punishment in some reasonable and genuine circumstances. To this end, the Islāmic law of crimes stipulate some concepts upon which justice could be attained such as adherence to the concept of criminal responsibility and equality. (Mamman, 2011, 9) Regarding the first aspect (i.e. the concept of criminal responsibility), it is a trite principle under Sharī'ah that every person should be criminally responsible for his action or omission. This entails that every person shall be held responsible only for those criminal acts which he has personally committed or omitted. The implication of this concept under the Islāmic corpus juris can be explored as follows: Everybody should be held responsible for his/her actions or omissions jointly and/or separately. To this end, Allāh (S.W.T.) says:

"That no burden person (with sin) shall bear the burden (sin) of another." (Qur'ān 53: 38) 
In a similar verse He says:

“And no bearer of burdens shall bear another's burden, and if one heavily laden calls another to bear his load, nothing of it will be lifted even though he be near of kin..." (Qur'ān 35:18)

In yet another verse:

"Whoever goes right, then he goes right only for the benefit of his own self. And whoever goes astray, then he goes astray to his own loss. No one laden with burdens can bear another's burden. And we never punish until we have sent a messenger (to give warning)". (Qur'ān 17:15)

The foregoing provisions imply that nobody should be responsible for the action of his fellow human beings, except in a situation where they have jointly participated in the commission or omission of the act. Hence in such circumstance, they should be jointly and/or separately responsible for the act, as both of them are accomplice to one another. Another implication of the concept of criminal responsibility under the Shari' 'ah is that everybody who is criminally responsible for an offence shall be punished accordingly in line with the prescribed punishment in the law. Except those who are exempted by Shari' $a h$ from criminal liability as a result of lack of capacity and/or mensrea (evil intention) to commit a crime. These persons for instance include: the insane, a child, a sleeping person etc. To this end, the Prophet (S.A.W.) was reported to have said:

"Do you know that no any actions whether good or evil are recorded for the following: an insane person till he becomes sane; a child till he attains the age of puberty; and a sleeping person till he awakes. All are not responsible for what they do." (Al-Tirmidhī, 4:32)

The second aspect upon which justice could be attained is "equality". It is also one of the most important factors to be used for achieving the objective of the law of Qiṣās. Islām considers all people equal before the law, hence no one should claim superiority over and above another, or claim an immunity before the law. People should all be treated equally regardless of their biological status or affiliation or sex or background. One of the objectives of Sharī'ah is to prevent all people from violating the law, and also to maintain justice amongst all. To this end, Allāh (s.w.t) says:

"Verily! Allāh commands that you should render back the trusts to those whom they are due; and that when you judge between men, you judge with justice. Verily, how excellent is the teaching which He (Allāh) gives you, Truly, Allāh is Ever All-Hearer, All-Seer." (Qur'ān 4: 58)

One of the lessons to be learned from this verse is that justice is one of the fundamental issues that should not be compromised with. It is an integral part of the Islāmic judicial system, and it is essential in maintaining the neutrality of the law. Thus, people especially those in authority are mandated to do justice amongst their subjects even if it affects their interest. For this reason the Allāh(S.W.T.) says that the believers should stand out firmly on justice even if it can affect their interest, or their parents, or their relatives. For He (Allāh) described injustice as Hawā (lusts of heart). ${ }^{17}$ In a hadìth, narrated by Anas (R.A.), the Prophet (S.A.W.) was asked about the great sins, he said they include: to join others in worship with Allāh; to be undutiful to one parents; to kill a person (which Allāh has forbidden to be killed); and to give a false witness." (al-Bukhārī, 3:821) In addition, it is important to note that the issue of equality in Islām does not focus only on parties (such as free for free, slave for slave, etc.) but also on their actions. Thus, Islāmic law provides a "tit for tat" approach, i.e if anyone kills (intentionally), the same should be done to him. The same result will happen if he inflicts injury on a person, equal and proportionate harm should be inflicted on him. To this end, Allāh (S.W.T.) says:

"And we ordained therein for them: life for life, eye for eye, nose for nose, ear for ear, tooth for tooth, and wound equal for equal..." (Qur'ān 5: 45)

However, if one kills his fellow human being unintentionally, instead of him to be executed for Qiṣās, he can be subjected to the lesser penalty. (Ṭāhir, 2010, 403) To this end, Allāh (S.W.T.) says:

"Never should a believer kill a believer, except by mistake. And whoever kills a believer by mistake, it is ordained that he should free a believing slave, and pay compensation to the deceased's family, unless they remit it freely. If the deceased belonged to people at 
war with you, and he was a believer, the freeing of a believing slave is enough. If he belonged to people with whom you have a treaty of mutual alliance, compensation should be paid to his family, and a believing slave be freed. For those who find this beyond their means, a fast for two consecutive months is prescribed by way of repentance to Allāh for Allāh hath All knowledge and All wisdom." (Qur'ān 4: 92)

The law of Qiṣās according to classical scholars is governed by three principles, namely: the principle of private prosecution; the principle that provides for redress in retaliation or financial compensation; and the principle of equivalence, which means that Qiṣāṣ is only allowed if the monetary value of the victim is the same as or higher than that of the perpetrator. (Rudolph, 38-50) This implies that the yardstick for determining equivalence as far as classical interpretation is concerned, is a person's status to which a monetary value is attached. This status can be determined by sex, religion, and by whether a person is a slave or a free person. The principle of equivalence prescribes that a person may not be sentenced to death for killing a person of a lower monetary value. (Rudolph, 38-50) However, according to the contemporary approach, if a person has deliberately or heinously murdered his fellow human being, it does not matter who the perpetrator and the victim were, the perpetrator should equally be sentenced to death. (Mukarram, 10) The victim's status or monetary value does not affect the position of intentional homicide (murder) punishable with death sentence (Qiṣās ). (Mukarram, 10)

It is also important to note that the liability for Qișās has not been limited only to deliberate causation of a victim's death but also as a result of death caused by criminal omission. However, there are differences of opinions regarding the liability of death caused by criminal omission. According to Hanafī jurists, criminal omission by a person who ought to have discharged his responsibility does not make him liable to the offence of wilful homicide, since the requirement for retaliation in Qișa $\bar{s}$ cases is that the perpetrator has to commit a positive act that has directly caused the victim's death i.e the murder must be the result of the act of the accused person otherwise it can ceased to be a murder. (Anwarullāh, 35) However the Shāfi' 'i and Hanbali jurists are of the opinions that the perpetrator would be liable for the Qișạs if the omission has been merely linked to a positive act of the accused person. For instance, if the perpetrator imprisoned the victim or withheld his food or drink to the extent of causing his/her death; or if the midwife negligently fails to tie off the umbilical cord of a newly born baby after cutting it, which resulted to a death of the baby. Similarly, the Mālikī jurists are also of the view that if a person omits to discharge what is required of him, and if such omission inevitably results in the death of another person, he can be sentenced to death by way of Qișās (Stephanie, 2008, 15:1) But if the omission is not likely to cause the death of a person, then he will not be liable for Qiṣāṣ. (Anwarullāh, 35) For instance, if a group of people (such as a caravan) continued to proceed with their journey after one of them fall down and subsequently got missing, then later was found dead. The group will not be liable for Qiṣaș because of their continuity with the journey, provided that they have searched for him. In fact, their actions had not inevitably resulted in the victim's death. (Stephanie, 2008, 15:1)

Furthermore, infliction of the Qișās punishment also depends upon the perpetrator's intent. It can only be executed on the accused if the commission or omission was intentional, otherwise the victim or his kin may alternatively be entitled to financial compensation (diyah). (Anwarullāh, 36-37) Some Mālikī jurists have emphasized on the intention of the accused in determining whether or not the offence committed should be considered as murder, which can result to a Qișās. However, other jurists, especially the Hanafis, have emphasized more on the nature of the weapon used by the accused person, in determining whether or not the accused is guilty of murder. If the weapon used, by its nature is likely to cause a death of the victim, then it can be regarded as murder, hence the intention of the accused is immaterial in this context. (Anwarullāh, 36-37)

A Murder or homicide according to the Sunni legal schools can be classified into two, namely: a homicide that is capable of Qiṣas ș and the one that is not capable of Qiṣaș. ('Audah, 6-7) This classification brought about further division of homicide as either intentional (Qatl 'amd $)^{18}$ or unintentional/accidental 
(Qatl khata'). ${ }^{19}$ In addition, the Sunni legal schools of Islāmic jurisprudence, except the Mālikī school, have also introduced another category of homicide, (Mukarram, 1-4) namely: Quasi-intentional homicide (Qatl shibh 'amd). ${ }^{20}$ However, the Mālikī school on the other hand has introduced another type of homicide to be known as heinous murder (Qatl ghilla). ${ }^{21}$ The implication for this classification in this context is to determine the appropriate punishment set out for each offence. Some offences require Qiṣās (retaliation) while some attracts only blood price (diyah) and kaffārah (expiation). Basically, intentional killing (Qatl 'amd) and heinous murder (Qatl ghīla) require Qiṣās (death penalty). The other category of homicide only attracts diyah and kaffārah punishments.

In establishing the intent of accused persons, Islāmic jurists have confirmed that it is very difficult to ascertain a person's state of mind, for it is only Allah (S.W.T.), the Creator, that can tell the actual mind of human beings. However, the jurists have made efforts to devise some external and objective criteria for ascertaining the intent of the accused persons. This includes the type of weapons used in committing the offence and the circumstances surrounding the killing of the victim. (Anwarullāh, 36-37) As mentioned earlier regarding the type and nature of the weapons, the law presumed that death or injury is intentional if the weapons used are such that normally cause death or injury. (Anwarullāh, 36-37) This is the opinion of some Hanafī jurists such as Abū Yūsuf and al Shaibānī. Similarly, even the founder of the school, Abū Hanīfa was of the view that homicide is regarded as intentional if the killer used fire or sharp object that can penetrate through human body (such as knife, sword, or sharp objects). (Anwarullāh, 36-37) However, the Mālikī jurists do not only look at the type of the weapon used in killing the victim, but also the circumstances surrounding the killing of the victim. This also brings about the second criteria for ascertaining the intent of the accused person in the homicide cases, i.e circumstances behind killing the victim. According to the Mālikī school, any person killed for his money or valuable things after having him treacherously brought to an isolated place, is said to have been killed intentionally and heinously (Qatl ghīla). (Anwarullāh, 36-37)

In view of this, any person who has been found guilty or convicted for intentional killing of his/her fellow human being should be punished in the like manner but subject to the rules and procedure governing Qiṣās. In some circumstances the relationship between the murderer and the victim, or between the next of kin and the offender, affects the application of Qișās or sometimes mitigates the punishment to a lesser one. For instance, all the four Sunni legal schools agree that a father or even his ascendants such as grandparents from the paternal or maternal side (i.e according to the opinions of Shāfi' '⿳亠丷厂 , Hanafī and Hanbalī jurists), cannot be sentenced to death for killing his child or his descendants (such as a grandchild). (Mukarram, 136) However the waiver does not apply in cases of children killing their parents or grandparents. ('Audah, 130) It is also important to note that there should be no Qiṣās against the offender if his child is among the heirs of the victim. ('Audah, 130) For instance, if a person killed his mother-in-law, and subsequently killed his wife, his wife's right to demand retaliation against him for the murder of her mother will be inherited by their children. Since then the perpetrator's children are among the prosecutors, hence Qișās cannot be demanded for the both acts of murdering his mother-in-law and his wife. ('Audah, 130) Similarly, under Shāfi' '̄̄ and Hanbalī schools, no person shall be subjected to Qiṣās if he inherits the right to demand the death penalty against himself. Since a killer cannot inherit from his victim, he can only acquire this right by inheriting it from someone else. (Mukarram, 136) For instance, if a person killed his childless brother in-law, his wife is then one of the prosecutors. If she dies before the sentence, the perpetrator himself inherits this right. Therefore, he should not prosecute himself, hence based on this he cannot be sentenced to death. (Mukarram, 136)

It is also important to understand that no Qiṣa $\bar{s}$ should be subjected to a freeperson in murdering a slave. However, the Hanafī jurists stipulate capital punishment in the case of a freeperson murdering a slave, but the penalty can be waived if the murderer is himself the slave's master, since he is equally the prosecutor.(Rudolph, 38-50) Unlike the opinion of 
jurists in other legal schools, the Mālikī jurists maintained that a father can be sentenced to death for killing his child intentionally or heinously, for that is the actual meaning of the Prophetic Hadīth. (Anwarullāh, 36-37)

\section{Conclusions}

Qișās has been prescribed in the Qur'ān and Sunnah of the Prophet (S.A.W.) as one of the punishments set out by Allāh (S.W.T.) in order to prevent violations of human rights and to curb the excesses of transgressors. Thus, Qișās brings about sanity and order in the society, as it can always serve as deterrence to people. Justice is an essential part of Qișās, especially the concept of "justice for all", which can be attained through the concepts of criminal responsibility and equality. Based on these concepts, murderers regardless of their status or positions, should be subjected to the punishment of Qișās. Hence, they can ripe what they sow in a like manner. However, in some circumstances, the punishment can be mitigated or waived. For instance, in a situation where a father killed his child, he could be granted a Qiṣa ș waiver according to some opinions if it was done unintentionally. To this end, the paper therefore concludes that law of Qiṣās applies to everyone regardless of some limitations that are involved. The paper equally reveals that mitigation of the Qișās punishment or the waiver awarded to parents should not be considered as immunity. In view of this, the paper suggests to revisit the Qișās waiver based on the emerging trend of the systematic violation of human rights in contemporary society. This can be achieved in two ways, namely: by using the concept of Maqāsid alSharī'ah as instrumental to the suggestion; and by adopting the position of the Mālikī school of thought regarding the legal position of parents under Qișās law (as mentioned in this paper).

\section{References}

'Abd al-Rahmā̄n Shihābuddīn Al-Baghdadī, Irshād alSālik Ilā Ashraf al-Masālik Fī al- Fiqh Imām Mälik, vol. 1, (nd).

'Abd al-Qadìr 'Audah, Criminal Law of Islām (jināyāt), vol. iv, New Delhi, India, 1999.

'Abd al-Raḥmān Ibn Muḥammad Al-Jazīrī, Kitāb alFiqh 'Alā al-Madhāhib Al-Arba'ah (nd) Vol.5.
'Abd al-Wahhāb Ibn 'Alì Al-Baghdādī al-Mālikī, Kitāb Al-Talqinu Fì al-Fiqh al-Mālikī, Abū Uwāiz Mohammad (ed), Dār al-Kutb Al-'Ilmiyyah, Beirūt, Lebanon, 1st Edition, vol. 2, 2004.

Abū bakar Ibn Mas'ūd 'Alā'udddīn, Badāi'al-Sanāi' Fi al-Tartīb al-Sharāi', Dār al- Kutb Al'Ilmiyyah, vol. 7, 1986.

Ahmad Ibn 'Alī Ibn Hajar, Fath al-Bāri; Sharh Saḥ̄h Al-Bukhārī, Dār al-Ma'rifah, Beirūt, Lebanon (1959), vol. 12, Hadith No. 6469.

Al-Hilālī, Muhammad Taqì al-Dīn and Khan, Muhammad Muhsin; Translation of the Meanings of the Noble Qur'ān, in the English Language, Madina: Saudi Arabia, King Fahad Complex, 1982.

'Alì Ibn Khalläf (Ibnū Battāl), Sharh Saḥịh Al-Bukhārì, Maktabah Al-Rursd, Riyārd, Saudi Arabia, 2nd Edition, vol. 8.

Al-Māwardī, 'Alī Ibn Mohammad, Al-Thāwī Fì Fiqh Al-Shāfi ì, Dār al-Kutb al -'Ilmiyyah, 1st Edition, vol. 12, 1994.

Al-Murdawī, 'Alī Ibn Sulaymān, Al-Inșāf Fī Ma'arifat al-Räjih̆ Min al-Khilāf 'Alā Madhhab Al-Imām Ahmad Ibn Hanbal, Dār al-Ihyā̄' al-Turāth al'Arabī, Beirūt, Lebanon, 1st Edition, vol. 9, (1419 AH) or (1998 AD).

Al-Samarqandī 'Alā' Addīn, Tuhfat al-Fuqahā', Dār al-Kutb al-'Ilmiyyah, Beirūt, Lebanon, vol. 3, 1984.

Al-Sarakhasī (Shamsuddīn Abū bakr Muhammad), AlMabṣūt, Khalīl Mahyuddìn (ed), Dār al-Fikr, Beirüt Lebanon, (1st Version), 2000.

Anwarullāh, The Criminal Law of Islām, A.S Noordeen, Kuala Lumpur Malaysia, 1997.

Ashgar 'Ali Muhammad, "Implementation of Hudūd (or limits ordained by Allāh for serious crimes) in Malaysia" International Journal of Humanities and Social Science Vol. 2 No. 3; February 2012.

Fatwā No. 30793, 17th April, 2003, available at http://fatwa.Islāmweb.net/fatwa/index.php?pag

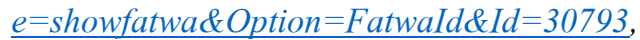
accessed on 08/11/2014.

Fatwā Nūr 'Alā Al-Darab, No.187507, available at http://Islāmqa.infolar/187507, accessed on 09/11/2014.

Hakim F.B et al., Policing Muslim Communities: Comparative International Context, Springer Science+Business Media New York 2012.

Hakim F.B; Haberfeld M.R; Verma A, The Concept of Punishment under Shari 'ah, at 14-16, available at http://wwwa.springer.com/978-1-4614-3551$\underline{8}$.

Ibn 'Uthaimin, Legal Position of Parents in respect of killing the child, available at 
http://www.ibnothaimeen.com/all/noor/article3 459.shtml, accessed on 15/09/2014.

Ibn Qudāmah, Mufiq al-Dīn 'Abdullāh Ibn Aḥmad Ibn Muhammad, Al-Mughnī, Maktab al-Qähirah, vol. 10,1968

Jamal Ahmed Bādī. Sharh arba'īn an- Nawawì: Commentry of Forty Hadith An - Nawawi, Hadith No. 17, at $p$ 89. Retrieved on 19th October 2013, <http://fortyhadith.iiu.edu.my>.

Javed Ahmad Ghāmidi \& Shehzad Salim, "The Penal Law in Islām”, Dār al-Tazkìr Islāmic Literature in Contemporary Language, Lahore, Pakistan (nd).

M. Mukarram Ahmed, Crimes and Punishment under the Islāmic Law, Anmol Publication, PVT. Ltd. New Delhi, India, 2008.

Mamman lawan, Ibrahim N. Sada, Shahir Sardar Ali, An Introduction to Criminal Justice: A Teaching and Learning Manual, The Higher Education Academy, UK Center for Legal Education, 2011

Muhammad Ibn Ahmad Ibn Rurshd, Bidāyat alMujtahid wa Nihāyat al-Muqtașid, Dār alHadith, vol. 4, 2004.

Muhammad Ibn Idrīs Al-Shāfi'ī, Al-'Umm, Dār alMa'rifah, Beirüt, Lebanon, vol.6, (1393 AH) or (1973 AD).

Muḥammad Ibn Yazìd Al-Qazwīnī, Sunan Ibn Mājah, Dār Al-Fikr, Beirūt, Lebanon, vol. 2, Hadìth No.2661, at 888 .

Mohammed Taufiq Ladan, Introduction to Jurisprudence: Classical and Islāmic, Malt house Law Books, Lagos Nigeria, 2006.

Muhammad Ibn 'îsā Al-Tirmidhī, Sunan al-Tirmidhì (Al-Jāmi' Al-Sahīh), Dār Al-Ihyā' Al-Turātha al-'Arabi, vol. 4, hadith No.1400.

Muhammad Ibn Ismā'īl, Sahīh Al-Bukhārī, EBook 4 Hadith Collections: Bukhari, Muslim, Malik and Dawūd, http://www.imaanstar.com.

Muhammad Nasr al-Dīn Al-Bāni, available at http://www.mahaja.com/showthread.php?3043, accessed on 15/09/2014.

Muhammad Nasr al-Dīn Al-Bāni, Irwā' Al-Ghalìl fì Takhrīj Al-hādith Al-Manār Al-Sabìl, AlMaktab Al-Islämī, Beirūt Lebanon, 2nd Edition, (1985), vol. 7.

Muslim Ibn Al-Hajjāj, Saḥih al-Muslim, Dār al-Ihyā Al- Turāth al- 'Arabī, Beirūt Lebanon, vol. 3, Hadith No.1678.

Muslim Ibn Al-Hajjāj, Sahịh al- Muslim, EBook 4 Hadīth Collections: Bukhārī, Muslim, Mālik and Da'üd, http://www.imaanstar.com.

Musnad Ahmad Ibn Hanbal, Muassat Al-Risālah, 2nd Edition, (1999), Hadith No. 147, vol. 1

Rudolph Peters, Crimes and Punishments in Islāmic Law, Theory and Practice from Sixteenth to
Twenty-First Century, Cambridge University Press, UK, 2005

Sayyid Qutb, Social Justice in Islām; translated by John B. Hardie, Revised by Hamid Algar, Islāmic Publication International, New York, USA. (ND)

School of Law, Defining Future of Legal Education, Round Table Discussion on "Qisās" and "Diyat" Law within the Criminal Justice System, Pakistan, September 21st 2013.

Stephanie Palo, "A Charade of Change: Qisās and Diyat Ordinance allows Honor killings to go unpunished in Pakistan", University of California, Davis [Vol. 15:1 2008] A Charade of Change.

Tahir H. Watsi, "The Law on Honour Killing: A British Innovation in the Criminal Law of the Indian Subcontinent and its Subsequent Metamorphosis under Pakistan Penal Code", A Research Journal of South Asian Studies Vol. 25, No. 2, July-December 2010.

Yahyā Ibn Sharaf, Muhyiddīn, Rawdat al-Tālibìn wa Umdat al- Muftīn, Al-Maktabah al-Islāmī, Beirūt, Lebanon, 1991.

Yūsuf Ibn 'Abdullāh Ibn Muhammad Ibn 'Abd al-Bārī Al-Qurtubī, Al-Kāfi Fì Fiqh Al-Madinah, Maktabah al-Riyārd al-Hadithah, Kingdom of Saudi Arabia, 2nd Edition, vol. 2.

\section{Endnotes}

${ }^{1}$ School of Law, Defining Future of Legal Education, Round Table Discussion on "Qisās" and "Diyat" Law within the Criminal Justice System, Pakistan, September $21^{\text {st }}, 2013$.

${ }^{2}$ Qatl al-Ghila is a type of homicide committed intentionally or heinously against the victims, which aimed at confiscating the victim's wealth or property. Sometimes it can be committed by hired killers in order to accomplish the mission of their hirers. In some circumstances, the nature of killings and the weapons used also determines and qualifies the act as Qatl al-Ghila. For instance, it is a prima facie evidence to believe that al-Ghila occurs if a person has been slaughtered with knife or crucified.

${ }^{3} \mathrm{Ta} z \bar{z} \bar{r}$ is an Arabic word which can be interpreted as "disciplinary measure" or "discretionary punishment". It can be applied discretionarily against any wrong which punishment has not been prescribed in the Holy Qur'ān or Sunnah of the Prophet (s.a.w.). Hence, such punishment can be imprisonment, or fine or lashes or all.

${ }^{4}$ Javed Ahmad Ghāmidi \& Shehzad Salīm, "The Penal Law in Islām”, Dār al-Tazkir Islamic Literature in Contemporary Language, Lahore, Pakistan

5 Fatwā No. 30793, 17 $7^{\text {th }}$ April, 2003, available at http://fatwa.islamweb.net/fatwa/index.php?page=showfatwa\&Option=Fat waId\&Id $=30793$, accessed on 08/11/2014

6 Fatwa No. 30793, 17 $7^{\text {th }}$ April, 2003, available at http://fatwa.islamweb.net/fatwa/index.php?page=showfatwa\&Option=Fat waId\&Id $=30793$, accessed on 08/11/2014

Fatwā No. 30793, $17^{\text {th }}$ April, 2003, available at http://fatwa.islamweb.net/fatwa/index.php?page=showfatwa\&Option=Fat waId\&Id $=30793$, accessed on 08/11/2014

8 Fatwā Nūr Alā Al- Darab No.187507, available at http://islamqa.info/ar/187507, accessed on 09/11/2014

${ }^{9}$ Muḥammad Ibn Ismā'ìl, Sahīh Al-Bukhārī, Book 1, Vol. 2, Hadìth No. 38. The position of this Hadith reinterates the verses in the Qur'ān which provides: "...Allah intends for you ease, and He does not want to make things difficult for you... Qur'ān 2: 185”. In yet another verse: “...Allāh 
does not want to place you in difficulty...Qur'ān 5: 6". Furthermore, "And strive hard in the course of Allāh as you ought to strive. He has chosen you, and has not let upon you in religion any hardship... Qur'ān 22: 78

${ }^{10}$ Narrated by Al-Baihaqī in Sha'ab al- īmān, 6651/261/5. However, Sheikh Al-Bānī in his Silsila al- Da '̌̈fah, 7056 has declared the Hadīth as weak.

${ }^{11} \mathrm{Ibn}$ 'Uthaimeen, Legal position of Parents in respect of killing the child, available at

http://www.ibnothaimeen.com/all/noor/article3459.shtml, accessed on $15 / 09 / 2014$

${ }^{12} \mathrm{http}: / /$ www.h-alali.cc/fopen.php?id=7e51d5581f-1029-a62a-0010dc1f69 accessed on 15/09/2014

${ }^{13}$ Ibn 'Uthaimeen, Legal Position of Parents in respect of killing the child, available at

http://www.ibnothaimeen.com/all/book...le,18245.shtml, accessed on $15 / 09 / 2014$

${ }^{14}$ Ibn 'Uthaimeen, Legal Position of Parents in respect of killing the child, available at

http://www.ibnothaimeen.com/all/book...le,18245.shtml, accessed on $15 / 09 / 2014$

15 Muhammad Nasir-ud- Deen Albani, available at http://www.mahaja.com/showthread.php?3043, accessed on 15/09/2014

${ }^{16}$ Cited in Javed Ahmad Ghāmidī \& Shehzad Salīm, "The Penal Law in Islām", Dār al-Tazkīr Islamic Literature in Contemporary Language, Lahore, Pakistan

${ }^{17}$ Qur'ān 4: 135, in which, Allāh (s.w.t.) says: "O you who believe! stand out firmly for justice, as witness to Allah, even though it be against yourselves, or your parents, or your kin, be the rich or poor, Allah is better protector to both (than you). So, follow not the lusts (of your heart), lest you avoid justice; and if you distort your witness, or refuse to give it, verily, Allah is ever Well-Acquainted with what you do."

${ }^{18}$ This is a type of homicide of which the actus reus (wrongful act) was intended and subsequently resulted to the death of a victim

${ }^{19}$ This is a type of homicide of which neither the actus reus (wrongful act) nor the consequence was intended. For instance, if a hunter aims his gun at an animal, wanting to shoot it, but unfortunately hits a person and resulted to his death. It can be considered as accident; hence it is unintentional killing.
${ }^{20}$ This is a type of homicide of which only the act and not the result was intended; for instance, if a person beats another with a cane or throws a pebble at him by way of jest and the other person dies or loses an eye as a result.

${ }^{21}$ This is a type of homicide committed heinously against the victim. For instance, if a person has been killed for his money after having him treacherously brought to an isolated place, is amount to Qatl al-ghillah. 